\section{EDUCATION}

Research, Inovarion and Solutions on-line ${ }^{\oplus}$
Electronic Journal of Research

in Educational Psychology

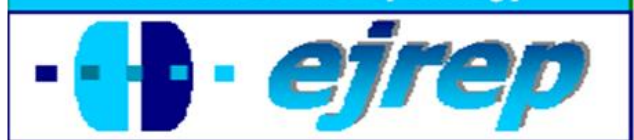

\title{
Family- and School-related Factors in 9- to 15-Year-Olds Predicting Educational Attainment in Adulthood: A Prospective 27-year Follow-up Study
}

\section{Mirka Hintsanen ${ }^{1}$, Taina Hintsa ${ }^{1}$, Päivi Merjonen ${ }^{1}$, Mare Leino $^{2}$, Liisa Keltikangas-Järvinen ${ }^{1}$. \\ ${ }^{1}$ IBS, Unit of Personality Work and Health Psychology, University of Helsinki, Helsinki \\ ${ }^{2}$ Institute of Social Work, Tallinn University, Tallinn.}

Finland, Estonia

Correspondence: Mirka Hintsanen. IBS, Unit of Personality Work and Health Psychology, University of Helsinki, P.O. Box 9, FIN-00014 University of Helsinki, Finland.

Email: mirka.hintsanen@helsinki.fi

(C) Education \& Psychology I+D+i and Editorial EOS (Spain) 


\begin{abstract}
Introduction. This prospective longitudinal study examined several selected family- and school-related factors simultaneously in order to investigate the importance of well known and less examined predictors of educational attainment.
\end{abstract}

Method. The participants were 844 (486 girls) nine-, 12-, and 15-years old comprehensive school students. Family- and school-related factors were assessed by parent- and self-reports in 1980. Educational attainment was assessed 27 years later in 2007 as educational level and years of completed education.

Results. Linear regression analyses showed that lower educational attainment was predicted by mother's and father's low education, strict disciplinary style of the mother, student's low school achievement, by student having received detention and by having taken part in remedial instruction.

Conclusion. Our findings stress the importance of early school achievement and the role of the family in supporting educational attainment. Furthermore, our results indicate that more research should be directed to examining school detention and remedial instruction and their effectiveness.

Keywords: educational attainment, school achievement, parental education, care-giving quality, school detention, remedial instruction. 


\section{Factores familiares y escolares de alumnos de 9 a 15 años, como predictores de su logro académico como adultos: Un estudio de seguimiento durante 27 años.}

\section{Resumen}

Introducción. El presente estudio prospectivo longitudinal examinó simultáneamente varios factores escogidos relacionados con la familia y la escuela, con el objetivo de estudiar la importancia de vaticinadores conocidos y menos estudiados de los logros educativos.

Método. Los participantes fueron 844 estudiantes (486 chicas) de segunda enseñanza de 9, 12 y 15 años. Los factores relacionados con la familia y la escuela se evaluaron basándose en los informes de los padres y los autoinformes de 1980. Los logros educativos se evaluaron 27 años más tarde en 2007 como el nivel educativo y los años de formación completada.

Resultados. Los análisis de regresión lineal demostraron que los logros educativos más bajos fueron pronosticados por el nivel inferior de la formación de la madre y del padre, por el estilo disciplinario estricto de la madre, por los éxitos escolares inferiores del estudiante, por haber estado castigado en la escuela y por haber participado en la enseñanza compensatoria.

Conclusión. Nuestros hallazgos enfatizan la importancia de los éxitos escolares tempranos y el papel de la familia en el apoyo de los logros educativos. Además, nuestros resultados indican que más investigaciones deberían ir dirigidas al estudio de los castigos en la escuela y a la enseñanza compensatoria y su eficacia.

Palabras clave: logros educativos, éxitos escolares, formación de los padres, calidad de atención, castigos en la escuela, enseñanza compensatoria. 


\section{Introduction}

Low academic achievement is an important predictor of social exclusion (Caspi, Wright, Moffitt, \& Silva, 1998). The tracking of academic achievement is high. Low school achievement predicts low achievement in later phases of school career and low educational attainment (Huurre, Aro, Rahkonen, \& Komulainen, 2006; Schmitt et al., 2009). For example, it has been shown that difficulties in reading and spelling predict lower school achievement and less ambitious choice of secondary education (Savolainen, Ahonen, Aro, Tolvanen, \& Holopainen, 2008). Therefore, early intervening targeted at improving prerequisites of successful schooling is important, and more information on early predictors of educational attainment is needed in order to prevent negative developmental trajectories leading to low education and high risk for social exclusion.

School achievement has been repeatedly shown to be related to parental education. A recent wide-scale meta-analysis shows that parental education correlates moderately $(r=0.30)$ with academic achievement (Sirin, 2005). In several studies, especially maternal education has been shown to play an important role, whereas paternal education has not, in many cases, been included (Mensah \& Kiernan, 2010; Ou \& Reynolds, 2008). For instance, maternal education of five-year olds has been shown to predict their educational attainment 21 years later (Flouri, 2006). However, there are also studies that have shown associations merely for father's education (Díaz, 2003).

Academic achievement shows close to as high heritability as intelligence (S. A. Petrill \& Wilkerson, 2000) and heritability is one reason for the comparatively high correlations between parental education and child's school achievement but there are also other explaining factors. For example, parents with higher education are suggested to create more motivating and supporting environment for studying, and it has been shown that higher educated parents provide more educational resources, such as reference books and a place where to study at home (Teachman, 1987). Furthermore, it seems likely that parents with higher education may show more interest in their child's schooling and school achievement, and it has been shown that parental involvement predicts academic achievement (Ou \& Reynolds, 2008). In addition, parental interest in child's education has been shown to predict the child's educational attainment 16 years later (Flouri, 2006). 
In addition to parental education, care giving quality is another potential predictor of school achievement and education. Furthermore, care giving quality may be one factor that mediates the effects of parental education on child's school achievement, as indicated by a finding showing that maternal education is associated to more nurturing child rearing practices (Jones, Rickel, \& Smith, 1980). Care giving quality is a marker of wider emotional atmosphere in the family (connected to parental satisfaction with life, the spouse, and the child) that can be used as indicator of favorable or unfavorable childhood environment (KeltikangasJärvinen, 2002). Parenting practices reflecting high care giving quality have been shown to predict students' school engagement and academic achievement, and these associations can be explained by mediation through parental school involvement and academic encouragement they give to their offspring (Steinberg, Lamborn, Dornbusch, \& Darling, 1992).

As mentioned above, it has been shown that low academic achievement in the early school stages predicts lower educational attainment later in life (Huurre et al., 2006) but in addition to this and to the family-related factors discussed above, there are also several other less examined school-related factors that could affect educational attainment. More research on these factors is needed. It should be examined whether there are specific markers along the school career that predict low educational attainment. Furthermore, an important question concerns the long-term effectiveness of the support offered by the schools. Is the level of support adequate?

The current prospective study examines the role of several selected family- and school-related factors in predicting educational attainment 27 years later in adulthood in a Finnish population-based sample. More specifically, mother's and father's education, care giving quality, student's academic achievement, taking part in remedial instruction and getting detention are examined. Including various family- and school-related measures gives a possibility to compare their relative importance and to find out whether their effects on educational attainment are independent of one another.

The Finnish school system is very homogenous. Finnish schools show little quality differences and little selection related to the students' demographic factors. Residential areas are not highly segregated and the vast majority of students are enrolled to the school nearest to their home. Private schools are almost non-existent. Teaching is organized around the same national curriculum in all schools, and all teachers receive university education reducing the 
differences between teachers. This rather homogenous environment offers a good setting for examining individual variance.

\section{Methods}

\section{Participants and procedure}

The participants were derived from the ongoing prospective "Young Finns" study that began in 1980. The subjects for the original sample in $1980(n=3,596)$ were selected randomly from six age cohorts (aged 3, 6, 9, 12, 15, and 18 years) in the population register of the Social Insurance Institution, a database that covers the whole population of Finland. The design of the study and the selection of the sample have been described in detail by Raitakari et al. (2008). The Young Finns cohort was enrolled into the study in 1980. 2,231 participants (62.0\% of the 1980 cohort) attended also in 2007 follow-up. For the current study, participants from three age groups were selected: Those aged 9, 12, and 15 in 1980, i.e. those attending comprehensive school. In these three age groups, there were 1185 participants who took part in the study also in 2007. In Finland, compulsory schooling begins in the year when the children turn 7 years old. The assessments of the present study were carried out in 1980 (school- and family-related measures) and in 2007 when the participants were aged 36, 39, and 42 years (educational attainment). There were 844 participants (358, 42.4\% men and 486, $57.6 \%$ women) who had full data on all study variables in 1980 and 2007. All the analyses were conducted on these participants. The mean age of the included participants was 39.0 years (in 2007). Participants gave written informed consent, and the study was approved by local ethics committees. Attrition has been examined in detail in the 21-year follow-up showing that participants that have remained in the sample are more often women and somewhat older but there are no differences between participants and dropouts in parent's years of education or in participant health assessed with several variables (Raitakari et al., 2008).

\section{Measures}

\section{Educational Attainment}

Participants educational attainment was assessed with a measure tapping achieved education in 2007. This variable was coded as follows: 1 - comprehensive school, 2 - high 
school or vocational education, 3 - bachelor's degree, or studies performed at the university but degree not completed, 4 - master's degree, and 5 - post-graduate degree. Educational attainment was additionally assessed with a variable indicating completed school years (including all school and education levels).

\section{Deficient Parental Care Giving Quality}

Deficient parental care giving quality (as indicated by intolerance of the parent towards the child, insignificance of the child to the parent, and strict disciplinary style) were self-rated by the parents (mostly mothers) in 1980 using a scale based on the Operation Family Study (Makkonen et al., 1981). Intolerance $(\alpha=0.66)$ was assessed with three items on a 5point scale, e.g. "In difficult situations the child is a burden", $1=$ not at all, $5=$ a great deal. Insignificance $(\alpha=0.63)$ was assessed with four items on a 5-point scale, e.g. "The child is significant to me“, 1 = very significant, $5=$ not significant. Strict disciplinary style $(\alpha=0.41)$ was assessed with two items on a dichotomous scale, e.g. "Disciplinary actions are often needed at home because of the aggressiveness of the child", 1 = Does not apply to the child, 2 $=$ Does apply to the child. Mean scores of these scales were formed so that high values represent deficient parental care giving quality, i.e. high intolerance, high insignificance and strict disciplinary style. The participants were required to have information on at least $50 \%$ of items of each scale to be included in the study.

\section{Mother's and Father's Education and Family Income}

Mother's and father's education were indicated by their years of education in 1980 . Childhood family income was assessed in with an 8-point scale of annual family income $(1=$ lowest income group, 8 = highest income group).

\section{School-related Factors}

School-related factors were collected with written questionnaires. They were reported by a parent. School achievement was assessed with grade point average of all school subjects in the student's last school report. In all subjects the grades range between 4 and 10 ( 4 = fail, 5-6 = poor, 7-8 = good, and 9-10 = excellent). Same criteria are used in all Finnish schools for grade giving. Detention was assessed by asking whether or not the student had been in school 
detention during the last term. Remedial instruction was assessed by asking whether or not the student had taken part in remedial instruction during the last term.

\section{Statistical Analyses}

The associations of early family- and school-related factors (predictors) with educational attainment (outcome) were examined with series of linear regression analyses. Analyses for each family- and school-related predictor were first conducted separately. Then the analyses were repeated so that all predictors were included in the same model. Two different regression models were constructed: The first model was adjusted for age and gender and the second model was adjusted for age, gender, childhood family income, mother's education and father's education (analysis that examined association between mother's / father's education and participant's educational attainment was naturally not adjusted by mother's / father's education). PASW software (versions 17 and 18) were used for the analyses.

\section{Results}

Table 1 presents the sample descriptive characteristics. Table 2 presents the linear regression analyses examining each family-related and school-related factor separately. Higher mother's and Father's education, student's higher academic achievement, and not participating in remedial instruction or detention were related to higher educational level and more completed years of education in a model where age and gender were adjusted for. Less strict disciplinary style was also associated with more years of education but not with educational level. These associations remained significant when mother's and / or father's education and childhood family income were additionally adjusted for.

Table 1. Descriptive characteristics of the Sample $(n=844)$

\begin{tabular}{lcccc}
\hline Variable (range) & Mean $(\mathrm{sd})$ & $\mathrm{n}$ & $\%$ \\
\hline Demographics & 39.0 & $(2.4)$ & & \\
Age & & & & \\
Gender & & & 486 & 57.6 \\
Girls & & & 358 & 42.4 \\
$\quad$ Boys & $5.2(1.8)$ & &
\end{tabular}


Family-related factors
Intolerance (1-5)
$1.99(0.63)$
Insignificance (1-5)
$1.55(0.47)$
Strict disciplinary style (1-2)
$1.06(0.18)$
Mother's years of eduction
$9.8(3.0)$
Father's years of education

School-related factors

Detention

Has been in detention

$121 \quad 14.3$

Has not

$\begin{array}{ll}723 & 85.7\end{array}$

Remedial instruction

Has had remedial instruction

$346 \quad 41.0$

Has not

$498 \quad 59.0$

School achievement $\mathrm{t}^{\mathrm{a}}$

$7.82(0.74)$

Educational attainment

Educational level

Comprehensive school

$36 \quad 4.3$

High school

$279 \quad 33.1$

Bachelor's level

$378 \quad 44.8$

Master's level

$127 \quad 15.0$

Post-graduate level

$24 \quad 2.8$

Years of education

$15.5(3.6)$

${ }^{\text {a }}$ Grade point average $(4=$ fail, $10=$ excellent $)$

${ }^{1}$ Income was assessed by an eight point scale, 1 representing lowest income and 8 representing highest income group.

Table 2. Separate Linear Regressions for Each School-related Factor and Family Factor Predicting Educational Attainment in Adulthood $(N=844)$.

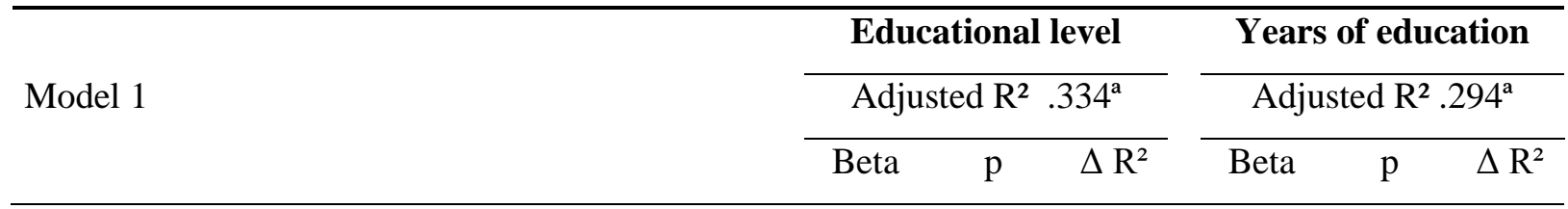


Family-related factors

$\begin{array}{lcccccc}\text { Intolerance } & -.043 & .213 & .002 & -.024 & .497 & .001 \\ \text { Insignificance } & -.066 & .055 & .004 & -.063 & .066 & .004 \\ \text { Strict disciplinary style } & -.053 & .124 & .003 & -.107 & \mathbf{. 0 0 2} & .011 \\ \text { Mother's years of eduction } & .372 & <.001 & .136 & .377 & <.001 & .139 \\ \text { Father's years of education } & .333 & <.001 & .109 & .313 & <.001 & .096 \\ \text { l-related factors } & & & & & & \\ \text { Detention } & -.094 & \mathbf{. 0 0 8} & .008 & -.099 & \mathbf{. 0 0 6} & .009 \\ \text { Remedial instruction } & -.219 & <.001 & .046 & -.228 & <.001 & .050 \\ \text { Grade point average } & .527 & <.001 & .248 & .489 & <.001 & .213\end{array}$

Model 2

Adjusted $\mathrm{R}^{2} .339^{\mathrm{a}}$

Adjusted $\mathrm{R}^{2} \cdot 300^{\mathrm{a}}$

Beta $\quad \mathrm{p} \quad \Delta \mathrm{R}^{2} \quad \begin{array}{lll}\text { Beta } & \mathrm{p} \Delta \mathrm{R}^{2}\end{array}$

Family-related factors

\begin{tabular}{lcccccc} 
Intolerance & -.043 & .174 & .002 & -.024 & .460 & .001 \\
Insignificance & -.055 & .076 & .003 & -.053 & .091 & .003 \\
Strict disciplinary style & -.027 & .395 & .001 & -.080 & $\mathbf{. 0 1 1}$ & .006 \\
Mother's years of eduction $^{1}$ & .241 & $<.001$ & .035 & .264 & $<.001$ & .041 \\
Father's years of education $^{\mathbf{0}}$ & .133 & $\mathbf{. 0 0 1}$ & .010 & .092 & $\mathbf{. 0 2 9}$ & .005 \\
l-related factors & & & & & & \\
Detention & -.103 & $\mathbf{. 0 0 2}$ & .010 & -.109 & $\mathbf{. 0 0 1}$ & .011 \\
Remedial instruction & -.147 & $<.001$ & .020 & -.158 & $<.001$ & .023 \\
Grade point average & .444 & $<.001$ & .162 & .405 & $<.001$ & .135 \\
\hline
\end{tabular}

Model 1 - Adjusted for age and gender.

Model 2 - Adjusted for age, gender, childhood family income, mother's years of education, and father's years of education.

${ }^{a}$ Calculated including control variables of the model and all family- and school-related factors.

${ }^{1}$ Not adjusted for mother's years of education.

${ }^{\circ}$ Not adjusted for father's years of education.

In addition to results reported in Table 2, we run some additional analyses. When all family- and school-related factors were included in the same regression model adjusting for age and gender, higher mother's education and student's academic achievement were associated with higher educational level $(\beta=0.211, \mathrm{p}<0.001 ; \beta=0.454, \mathrm{p}<0.001$, respectively) and more completed years of education $(\beta=0.241, \mathrm{p}<0.001 ; \beta=0.396, \mathrm{p}<0.001$, respectively). Higher father's education was associated with higher educational level $(\beta=0.101, p=$ 
$0.005)$ but not with more years of education $(\beta=0.070, p=0.059)$. Except for father's education, these associations remained significant when mother's and / or father's education and childhood family income were additionally adjusted for.

\section{Discussion}

The current study was conducted to simultaneously examine various childhood factors in relation to educational attainment 27 years later in adulthood. Our results showed that several school-related factors as well as several family factors predicted educational attainment but only consistent independent predictors were mother's education and participant's own school achievement in comprehensive school, both of which predicted higher educational attainment.

Our results on mother's education and participant's own school achievement are in line with previous research that has repeatedly shown these associations (Flouri, 2006; Huurre et al., 2006). Going beyond much of the previous research, our results show that these factors are important predictors of educational attainment independent of several other factors such as care giving quality, and school related factors like taking part in remedial instruction. Our results show that father's education also plays an important role although mother's education seems to be even more important. In similar vein, we have previously found that a combination of mother's and father's education and family income predicts educational attainment in a working population (Hintsa et al., 2006).

We also included several potential but less examined predictors of educational attainment. Indicators of parental care-giving quality were not associated with educational attainment except for the association between strict disciplinary style and less years of education. Finding so few associations for care-giving quality is interesting because in the Young Finns data which was used in the current study, lower child-rearing quality has previously been found to predict several outcomes such as lower self-esteem (Keltikangas-Järvinen, Kivimäki, \& Keskivaara, 2003), higher dispositional pessimism (Heinonen, Räikkönen, \& KeltikangasJärvinen, 2005), higher depressive symptoms (Katainen, Räikkönen, Keskivaara, \& Keltikangas-Järvinen, 1999), higher work stress (Hintsanen et al., 2010), and in girls, higher level of cardiovascular risk factors (Ravaja, Katainen, \& Keltikangas-Järvinen, 2001). Therefore, it is 
not that child-rearing quality would not be an important factor that truly affects the development of the child, only its role in explaining educational attainment seems not to be of primary importance in the current study. These findings indicate that the association of mother's and father's education with the educational attainment of their offspring is not likely to be mediated by child-rearing quality except for strict disciplinary style. The current results do not deny that other aspects of care-giving quality, not assessed in the current study, can be associated with educational attainment. Indeed, another recent study reported that supportive parenting did mediate the relation between parental education and subsequent student educational attainment (Melby, Conger, Fang, Wickrama, \& Conger, 2008). The future studies should assess several aspects of care-giving, as was done in the current study but representing still wider range of different aspects of care-giving quality, to be able to specify what aspects are the most relevant predictors for student's educational attainment.

Another possible mediator is an achievement oriented family environment. This presumption is supported by the findings showing these factors to be related to academic achievement (Kurdek \& Sinclair, 1988). Another explanation for the association between mother's education and participant's educational attainment is that higher maternal education has been shown to be related to child's use of more effective problem-solving strategies (Jones et al., 1980), which in turn may affect educational attainment. Genetic reasons (Keltikangas-Järvinen et al., 2010; Pulkki-Råback et al., 2010) and inherited cognitive ability are naturally also among the possible explanations. However, still more research is needed to find out which are the most important mediating factors between maternal education and educational attainment and to find out if there are practices that could be taught to the parents in order to help them support their children's educational careers.

Getting detention predicted lower educational attainment. It is maybe even a bit surprising how far a simple measure of having gotten detention during a single school term could reach its effect. One reason for this is that getting detention may act as a marker of behavior problems, which may have an enduring detrimental effect to the educational career. Furthermore, being subjected to disciplinary actions, such as detention, may reflect low social integration. Poor integration into family, peer and school settings, in turn, has been shown to predict lower educational attainment (Glendinning, Hendry, \& Shucksmith, 1995). On the other hand, getting detention may affect the way the student perceives school and learning. Especially getting detention when it is perceived to be unfair could diminish motivation and bring 
about negative attitudes towards the school which may lead to lower achievement and eventually to lower educational attainment.

An example of a more positive alternative for detention is developing restorative justice centers (Ashworth et al., 2008). Their idea is to give the students a possibility to reflect their actions, think of better solutions that can be used when similar situations provoking undesirable behaviors are encountered again, and to help the students to find ways to make up for the harm they have caused by their actions. The aim is to help the victims as well as the misbehaving student (Ashworth et al., 2008).

We also found that taking part in remedial instruction predicted lower academic attainment. The students taking part in remedial instruction are likely to be somewhat selected group as only those who are struggling with their school work are offered remedial instruction. What our results reveal is that the long-term effects of remedial instruction are not so strong that the differences between those who took part in remedial instruction and those who did not would have been abolished. This is not to say that remedial instruction is not effective. It may well be that those who took part in remedial instruction would have been far worse off without it. What we mean to say is that at that form in which the remedial instruction was given, it was not sufficient to remove the differences between those who participated and those who did not need to participate.

There are several possible reasons for this. First of all, there may be individual differences that remedial instruction, irrespective of how it is arranged, may not be able to remove. This kind of differences may be for instance related to interests, motivation and also to cognitive ability. Furthermore, the length or density of the sessions and the duration of the remedial instruction period may not have been adequate. It is also possible that offers of remedial instruction have been given too late so that the student has already lagged too far behind from others to be able to catch up. It has been previously shown that when remedial instruction has been given at an earlier age it has been more effective showing faster and longer lasting effects than remedial instruction given at a later age (Leino, 1996). However, effects of remedial instruction should be compared to its financial costs. Future studies should examine whether investing in decreasing class size would be more effective than similar investment directed to remedial instruction. 


\section{Limitations and Methodological Considerations}

There are some limitations to our study. Family- and school-related factors were reported by a parent and not with more objective means, such as school records. This may have introduced some error to our measurements. For example, it has been found that self-reported school grades contain some bias (Kuncel, Credé, \& Thomas, 2005). However, systematic bias similar in the predictors and the outcomes (that could increase the risk for erroneous findings) is likely to be reduced by the time-lag between the measurements (Podsakoff, MacKenzie, Lee, \& Podsakoff, 2003), which was extensive in the current study.

By the time of the data collection of the current study in 1980, the National Board of Education in Finland instructed the schools in a nation-wide six page guideline on remedial instruction that remedial instruction should be given to the student if the student is in danger to lag behind from others (Kouluhallitus, 1980). Furthermore, it was instructed that in each class, two hours per week can be used and that remedial instruction is given individually or in small groups and in individually tailored format. In addition, municipalities were obliged to ensure that the instructions were followed by the schools (Kouluhallitus, 1980).

Despite these rather specific instructions, practices of remedial instruction and selecting students to remedial instruction are likely to slightly vary between schools, and as we do not have specific information about the way remedial instruction was implemented, we cannot give recommendations on how practices should be changed. However, our findings hint that more research on remedial instruction and its effectiveness should be conducted. Collecting more specific information is recommendable in the future studies. This holds for examining detention as well.

Despite the limitations, the strengths of our study outnumber the limitations.

We used a considerably large population based sample and were able to follow the same participants for 27 years. We used parent- and self-reports, i.e. had more than one data source. Furthermore, educational attainment was assessed with two different measures (education level and years of completed education) and very similar results were found for both of these, which gives credence to our findings. As Petrill and Justice (2007) note, limited effectiveness of educational interventions is raising increasing concerns among educational researchers. Clearly, more knowledge on factors affecting success in educational career is needed. By in- 
vestigating several well known and several less examined family- and school-related factors simultaneously, our study aimed to help achieve this goal.

\section{Conclusions}

We were able to show that several childhood factors were predictive of educational attainment in adulthood 27 years later. High maternal education and student's school achievement were the most important predictors but father's education, less strict disciplinary style, having not received detention and having not taken part in remedial instruction during the latest term were also predictive of higher educational attainment. Our findings stress the importance of early school achievement and the role of the family in supporting academic attainment. Furthermore, our results indicate that more research should be directed to examining school detention and remedial instruction and their effectiveness.

\section{Acknowledgements}

This study was supported by the Academy of Finland (grant 124399 LKJ) Emil Aaltonen Foundation ( $\mathrm{MH})$, and Signe and Ane Gyllenberg Foundation (MH), Ella and Georg Ehrnrooth (MH), Jenny and Antti Wihuri Foundation (PM). 


\section{References}

Ashworth, J., Van Bockern, S., Ailts, J., Donnelly, J., Erickson, K., \& Woltermann, J. (2008). The restorative justice center: An alternative to school detention. Reclaiming Children and Youth, 17, 22-26.

Caspi, A., Wright, B. R. E., Moffitt, T. E., \& Silva, P. A. (1998). Early failure in the labor market: Childhood and adolescent predictors of unemployment in the transition to adulthood. American Sociological Review, 63, 424-451.

Díaz, L. A. (2003). Personal, family, and academic factors affecting low achievement in secondary school. Electronic Journal of Research in Educational Psychology, 1, 43-66.

Flouri, E. (2006). Parental interest in children's education, children's self-esteem and locus of control, and later educational attainment: twenty-six year follow-up of the 1970 British Birth Cohort. British Journal of Educational Psychology, 76, 41-55.

Glendinning, A., Hendry, L., \& Shucksmith, J. (1995). Lifestyle, health and social class in adolescence Social Science \& Medicine, 41, 235-248.

Heinonen, K., Räikkönen, K., \& Keltikangas-Järvinen, L. (2005). Dispositional optimism: development over 21 years from the perspectives of perceived temperament and mothering Personality and Individual Differences, 38, 425-435.

Hintsa, T., Kivimäki, M., Elovainio, M., Keskivaara, P., Hintsanen, M., Pulkki-Råback, L., et al. (2006). Parental socioeconomic position and parental life satisfaction as predictors of job strain in adulthood: 18-year follow-up of the Cardiovascular Risk in Young Finns Study. Journal of Psychosomatic Research, 61, 243-249.

Hintsanen, M., Kivimäki, M., Hintsa, T., Theorell, T., Elovainio, M., Raitakari, O. T., et al. (2010). A prospective cohort study of deficient maternal nurturing attitudes predicting adulthood work stress independent of adulthood hostility and depressive symptoms. Stress: The International Journal on the Biology of Stress, 13, 425-434.

Huurre, T., Aro, H., Rahkonen, O., \& Komulainen, E. (2006). Health, lifestyle, family and school factors in adolescence: Predicting adult educational level Educational Research, 48(1), 41-53.

Jones, D. C., Rickel, A. U., \& Smith, R. L. (1980). Maternal child-rearing practices and social problem-solving strategies among preschoolers. Developmental Psychology, 16, 241242.

Katainen, S., Räikkönen, K., Keskivaara, P., \& Keltikangas-Järvinen, L. (1999). Maternal child-rearing attitudes and role satisfaction and children's temperament as antecedents 
of adolescent depressive tendencies: follow-up study of 6- to 15-year-olds. Journal of Youth and Adolescence, 28, 139-163.

Keltikangas-Järvinen, L. (2002). Psychology and the risk for cardiovascular disorder: A developmental perspective. In L. Bäckman \& C. von Hoften (Eds.), Psychology at the turn of the millenium (Vol. 1, pp. 335-353).

Keltikangas-Järvinen, L., Jokela, M., Hintsanen, M., Salo, J., Hintsa, T., Alatupa, S., et al. (2010). Does genetic background moderate the association between parental education and school achievement? Genes, Brain and Behavior, 9, 318-324.

Keltikangas-Järvinen, L., Kivimäki, M., \& Keskivaara, P. (2003). Parental practices, selfesteem and adult temperament:17-year follow-up study of four population-based age cohorts. Personality and Individual Differences, 34, 431-447.

Kouluhallitus. (1980). Yleiskirje Y 31/80. Retrieved. from.

Kuncel, N. R., Credé, M., \& Thomas, L. L. (2005). The validity of self-reported grade point averages, class ranks, and test scores: A meta-analysis and review of the literature $R e$ view of Educational Research, 75, 63-82.

Kurdek, L. A., \& Sinclair, R. J. (1988). Relation of eighth graders' family structure, gender, and family environment with academic performance and school behavior. Journal of Educational Psychology, 80, 90-94.

Leino, M. (1996). Probleemlaste taust. In M. Leino \& M. Männiste (Eds.), Probleemne laps tavakoolis (pp. 57-73). Tallinn: HK trükikoda.

Makkonen, T., Ruoppila, I., Rönkä, T., Timonen, S., Valvanne, L., \& Österlund, K. (1981). Operaatio perhe - Isä ja synnytys. Helsinki: Mannerheimin lastensuojeluliittoo. Document Number)

Melby, J. N., Conger, R. D., Fang, S.-A., Wickrama, K. A. S., \& Conger, K. J. (2008). Adolescent family experiences and educational attainment during early adulthood. Developmental Psychology, 44(6), 1519-1536.

Mensah, F. K., \& Kiernan, K. E. (2010). Gender differences in educational attainment: Influences of the family environment. British Educational Research Journal, 36, 239-260.

Ou, S.-R., \& Reynolds, A. J. (2008). Predictors of educational attainment in the Chicago Longitudinal Study. School Psychology Quarterly 23, 199-229.

Petrill, S. A., \& Justice, L. M. (2007). Bridging the gap between genomics and education. Maind, Brain, and Education, 1, 153-161.

Petrill, S. A., \& Wilkerson, B. (2000). Intelligence and achievement: A behavioral genetic perspective. Educational Psychology Review, 12, 185-199. 
Podsakoff, P. M., MacKenzie, S. B., Lee, J.-Y., \& Podsakoff, N. P. (2003). Common method biases in behavioral research: A critical review of the literature and recommended remedies. Journal of Applied Psychology, 88, 879-903.

Pulkki-Råback, L., Pullmann, H., Hintsanen, M., Alatupa, S., Ravaja, N., Lehtimäki, T., et al. (2010). Hyperactivity in childhood as a predictor of school performance in elementary school: Modifying effect of a serotonin receptor gene (5-HTR2A). Electronic Journal of Research in Educational Psychology, 8, 971-990.

Raitakari, O. T., Juonala, M., Rönnemaa, T., Keltikangas-Järvinen, L., Räsänen, L., Pietikäinen, M., et al. (2008). Cohort profile: The Cardiovascular Risk in Young Finns Study. International Journal of Epidemiology, 37, 1220-1226.

Ravaja, N., Katainen, S., \& Keltikangas-Järvinen, L. (2001). Perceived difficult temperament, hostile maternal child-rearing attitudes and insulin resistance syndrome precursors among children: A 3-year follow-up stuyd. Psychotherapy and Psychosomatics, 70, 66-77.

Savolainen, H., Ahonen, T., Aro, M., Tolvanen, A., \& Holopainen, L. (2008). Reading comprehension, word reading and spelling as predictors of school achievement and choice of secondary education. Learning and Instruction, 18, 201-210.

Schmitt, N., Keeney, J., Oswald, F. L., Pleskac, T. J., Billington, A. Q., Sinha, R., et al. (2009). Prediction of 4-year college student performance using cognitive and noncognitive predictors and the impact on demographic status of admitted students Journal of Applied Psychology, 94, 1479-1497.

Sirin, S. R. (2005). Socioeconomic status and academic achievement: A meta-analytic review of research Review of Educational Research, 75, 417-453.

Steinberg, L., Lamborn, S. D., Dornbusch, S. M., \& Darling, N. (1992). Impact of parenting practices on adolescent achievement: Authoritative parenting, school involvement, and encouragement to succeed. Child Development, 63, 1266-1281.

Teachman, J. D. (1987). Family background, educational resources, and educational attainment. American Sociological Review, 52, 548-557. 